\title{
Paediatric Obesity: An Anthropometric study of school children aged between (4-19) years
}

\author{
Pooja Gangrade Sajjan ${ }^{1}$, Rajeev Yadav ${ }^{2}$ \\ ${ }^{1}$ Professor and HOD, Dept of Anatomy, Govt Medical College, Raigarh, (C.G), ${ }^{2}$ Associate Professor, Dept of Community Medicine, \\ Govt Medical College, Jaipur (Rajasthan)
}

\section{A B S T R A C T}

Background: Worldwide spreading on an alarming rate the new non-communicable disease with less paid attention as compared to other nutritional studies: Obesity is catching the attention of medical practitioners and policy makers alike. Obesity trends are causing serious public health concerns not only in developed countries but also in the $3^{\text {rd }}$ world countries like ours. Objective: This report present the urban anthropometric data of school going children of the state of Chhattisgarh. The study states the prevalence of obesity and overweight among school children of Raigarh district and focuses on tabulating BMI charts for Chhattisgarh State population' as a data base is not available for the same till date. Materials Methods: Data was collected from school going children of an urban school at Raigarh aged between 4-19 years for both girls and boys. Data was subjected to statistical analysis and results obtained were compared with the WHO guidelines and also postulated by Indian Academy of Paediatrics. Total 4421 students were subjected towards anthropometric measurements. Result: The overall prevalence of obesity (i.e. Subjects having BMI more than $95^{\text {th }}$ percentile) was 5.01 percent. Among boys it was 4.98 percent whereas among girls it was observed at 5.05 percent. Overweight children who ranged between $85^{\text {th }}$ to $95^{\text {th }}$ percentiles recorded a total share of 9.97 percent which was seen as 10 percent in boys and 9.92 percent in girls. But in adolescent age groups the prevalence calculated was far more than expected. Conclusion: This latest data adds to the knowledge about the obesity trends in the newly developing state of Chhattisgarh and requires timely intervention by health authorities for its control.

Keywords: Obesity, overweight, paediatric

\section{INTRODUCTION}

World-over, many countries which come under the umbrella of being termed as developing nations, have been hit by the emerging epidemics of obesity and diabetes. This is particularly true for low and middle income group countries which from the major portion of worlds' population. ${ }^{1}$ In South- East Asia including India, there has been a noticeable transition in their economy and nutrition. ${ }^{2}$ These have led to change in the routine age old life style modifications. Economy has boosted the power of the common man to reach and enjoy the so called luxuries of life, this has brought about a considerable change in dietary habits, decreasing physical activity and rising prevalence of obesity as its side effect.
Obesity is a serious public health concern sparing only the dramatically poor regions with chronic food scarcity such as Sub Saharan and Haiti. More than 1.6 billion persons $>15$ year and are overweight or obese as per 2005 censes (WHO), contributing to around 2.6 million deaths worldwide every year. ${ }^{3-4}$ Obesity has not only exploited the adult age groups but is also causing a paediatric public health problem with risk of complications in child hood and thereby increasing the morbidity and mortality patterns throughout adult life.

\section{Epidemiology}

Childhood obesity affects both the affluent and the less privileged. It is prevalent in all socio demographic and socio-economic groups, irrespective of age sex or ethnicity. 
It has been estimated that worldwide over 22 million children under the age of 5 years are obese, and one in 10 children is overweight ${ }^{5}$.

In USA, the prevalence of obesity increased 300 percent over approximately 40 years. The National health and nutrition examination survey (NHANES) IV, 1999-2002, found 31 percent of children $>2$ years to be overweight or obese and 16 percent of children and adolescents aged 6-19 years were in the obesity range. ${ }^{3}$ Similar trends are seen in United Kingdom with prevalence of obesity seen as 21.8 percent in boys and 26.9 percent in girls. In the middle-east, highest incidence is seen in UAE, where one in five children are either obese of overweight. A recent review showed a prevalence of overweight youth in the developed countries like North America and European countries (France, Sweden, Germany, and Italy) to be from 5-15 percent. $^{6}$

The problem doesn't limit itself to only developed countries, Asian Countries are also not immune to this phenomenon, in China the prevalence of overweight and obesity amongst children aged 7-9 years increased from 1-2 percent in 1985 to 17 percent in girls and 25 percent in boys in $2000 .{ }^{7}$ In addition obesity prevalence varies across socio-economic strata, in developed countries children of low socio-economic status are more prone than their affluent counter parts, but the reverse is true for developing countries where in children of upper socio economic strata are more likely to be overweight or obese. ${ }^{8-9}$

Indian data on paediatric and adolescent obesity are emerging. Few studies that have been carried out in the past couple of years clearly state the rising patterns of obesity and overweight children in Indian subcontinent. Studies conducted in the southern parts of India show a high prevalence of obesity ranging from 3.4 percent to 5.3 percent; where as the overall overweight prevalence ranges from 8.5 percent to 18.5 percent. ${ }^{10-15}$

Countries like India, are burning their candles on both their ends as on one extreme we are fighting with malnutrition, infant mortality, paediatric morbidity and on the other extreme this new non communicable epidemic of obesity, which has extended the burden on health care sector.

\section{Etiopathogenesis}

Humans have the capacity to store energy in adipose tissue allowing improved survival chances in the times of famine. In simple terms obesity results from the imbalance of caloric intake and energy expenditure. Even incremental but sustained caloric excess results in adiposity. ${ }^{3}$

\section{Definition}

Obesity may be defined functionally as a maladaptive increase in the mass of somatic fat stores, whereas paediatric obesity will reflect both the likelihood that the child will become on obese adult with the present and future risk of adiposity related morbidity. ${ }^{16}$ The risk of co morbidities include cardio vascular disease, Type 2 Diabetes mellitus, asthma, hypertension, hyperlipidemia, non alcoholic fatty liver disease, chronic inflammation, poly cystic ovarian disease, orthopaedic diseases, certain cancers like colorectal carcinoma, sleep apnoea, and varied physiological and behavioural complications. ${ }^{3,16}$

The present study emphasises about the prevalence of obesity and overweight among school children of Raigarh district and also aims at formulating BMI charts for Chhattisgarh State population' as a data base is not available for the same till date.

\section{MATERIAL AND METHODS}

The study incorporates the primary analysis of anthropometric measurements of school children aged (4-19) years

- Study population: Children between the ages of (419) years studying in class's nursery - XII.

- Area of study: The present study was conducted at an urban school (O. P. Jindal High school) at Raigarh district in the state of Chhattisgarh.

- Period of study: from April 2014 -October 2014.

- Ethical consideration: The study had ethical clearance. The following approvals were obtained before conducting the study

1. From the principal O.P. Jindal High School Raigarh (C.G.)

2. From the Dean and ethical Committee, Late Shri Lakhiram Agrawal Memorial Govt. Medical College Raigarh.

- Selection of participants:

1. All children who has completed 4 years of age on the date of anthropometric measurement and were not more than 19 years of age.

2. Both girls and boys were in included in the study.

- Exclusion criterion

1. Children whose exact date of birth was not available.

2. Children who had physical deformities of limbs and spine.

3. Children who were suffering from disease.

- Sample Size: A total of 4114 students were included between the ages 4-19 out of which 2451 were boys and 1663 were girls. 
- Anthropometric Measurements: For the purpose of the present study, body weight was measured in kilograms and height was measured in centimetres.

- Body weight: The weight of each student was recorded accurately on an electronic weighing scale which had minimum unit of $100 \mathrm{~g}(0.1 \mathrm{~kg})$. The students were asked to remove their school shoes and any other heavy item like belts etc. and asked to stand with their chin parallel to the ground and on the centre of the weighing scale. A set of three readings was taken and recorded by the same observer and the lowest one was taken.

- Height : For standing height, students were asked to stand upright with shoes removed and heels slightly separated and weight being bone on both feet equally. Heels, buttocks, shoulder blades, head were all brought in contact with the vertical surface of the wall, with the head so positioned that the child looks directly forwards in Frankfort plane, head piece of stadiometer placed firmly over the head to compress, hair. A set of three readings was taken and recorded by the same observer and the lowest one was taken.

- $\quad$ BMI(Body mass index) : was calculated using the formula

$$
B M I=\frac{W e i g h t(K g)}{\text { Height (meter) X Height (meter) }}
$$

Health care professionals define obesity or increased adiposity using the body mass index (BMI) which is an excellent proxy for more direct measurements body fat. Children $\geq 2$ years of age with $B M I \geq 95^{\text {th }}$ percentiles meet the criterion for obesity and those between $85^{\text {th }}$ and $95^{\text {th }}$ percentiles fall in the overweight range. The terminology used for paediatric obesity previously was 'risk of overweight' and overweight. ${ }^{3,16}$

The data was subjected to statistical analysis and result obtained. BMI data was summarized as Mean \& Standard error of mean. Age specific centiles of BMI were calculated to make reference curves for boys, girls \& study population. Chi-square test was used to compare prevalence of obesity/ overweight between subgroups.'p' < 0.05 was taken as significant. SPSS $21^{\text {st }}$ version software was used for all statistical calculations

\section{RESULTS}

A list of detailed tables based on the anthropometric measurements and indices in the study are found in the following pages.

Prevalence of overweight and obesity was recorded highest (25.41 percent and 20.44 percent respectively) in age group 17 which was followed by ages 16 and 18 with prevalence of obesity nearing 15 percent and overweight nearing 21 percent.

The overall prevalence of overweight children (BMI between $85^{\text {th }}$ percentiles - $95^{\text {th }}$ percentiles) among children was 9.97 percent and prevalence of obesity was 5.01 percent. Prevalence of obesity and overweight among males was 4.98 percent and 10.00 percent respectively, whereas the prevalence of obesity and overweight was 5.05 percent and 9.92 percent in females respectively.

\begin{tabular}{|c|c|c|c|c|c|c|c|}
\hline \multirow[t]{3}{*}{ Age } & \multirow{3}{*}{$\begin{array}{l}\text { Total number } \\
\text { of examined } \\
\text { persons }\end{array}$} & \multicolumn{2}{|c|}{ Normal } & \multicolumn{2}{|c|}{ Overweight } & \multirow{2}{*}{\multicolumn{2}{|c|}{$\begin{array}{c}\text { Obesity } \\
\mathrm{BMI}>95^{\text {th }} \text { percentile }\end{array}$}} \\
\hline & & \multirow{2}{*}{$\begin{array}{c}\text { Number of } \\
\text { examined } \\
\text { persons }\end{array}$} & \multirow[t]{2}{*}{$\%$} & \multicolumn{2}{|c|}{ BMI between $85^{\text {th }}-95^{\text {th }}$ percentile } & & \\
\hline & & & & $\begin{array}{l}\text { Number of examined } \\
\text { persons }\end{array}$ & $\%$ & $\begin{array}{c}\text { Number of } \\
\text { examined persons }\end{array}$ & $\%$ \\
\hline 4 years & 257 & 257 & 100 & 0 & 0 & 0 & 0 \\
\hline 5 years & 284 & 281 & 98.94 & 2 & 0.7 & 1 & 0.35 \\
\hline 6 years & 324 & 318 & 98.15 & 4 & 1.23 & 2 & 0.62 \\
\hline 7 years & 311 & 302 & 97.11 & 9 & 2.89 & 0 & 0 \\
\hline 8 years & 284 & 270 & 95.07 & 12 & 4.23 & 2 & 0.7 \\
\hline 9 years & 322 & 308 & 95.65 & 10 & 3.11 & 4 & 1.24 \\
\hline 10 years & 296 & 258 & 87.16 & 32 & 10.81 & 6 & 2.03 \\
\hline 11 years & 318 & 281 & 88.36 & 27 & 8.49 & 10 & 3.14 \\
\hline 12 years & 321 & 263 & 81.93 & 40 & 12.46 & 18 & 5.61 \\
\hline 13 years & 293 & 226 & 77.13 & 46 & 15.7 & 21 & 7.17 \\
\hline 14 years & 308 & 226 & 73.38 & 63 & 20.45 & 19 & 6.17 \\
\hline 15 years & 257 & 180 & 70.04 & 43 & 16.73 & 34 & 13.23 \\
\hline 16 years & 311 & 199 & 63.99 & 67 & 21.54 & 45 & 14.47 \\
\hline 17 years & 181 & 98 & 54.14 & 46 & 25.41 & 37 & 20.44 \\
\hline 18 years & 44 & 28 & 63.64 & 9 & 20.45 & 7 & 15.91 \\
\hline 19 years & 3 & 3 & 100 & 0 & 0 & 0 & 0 \\
\hline Total & 4114 & 3498 & 85.03 & 410 & 9.97 & 206 & 5.01 \\
\hline
\end{tabular}




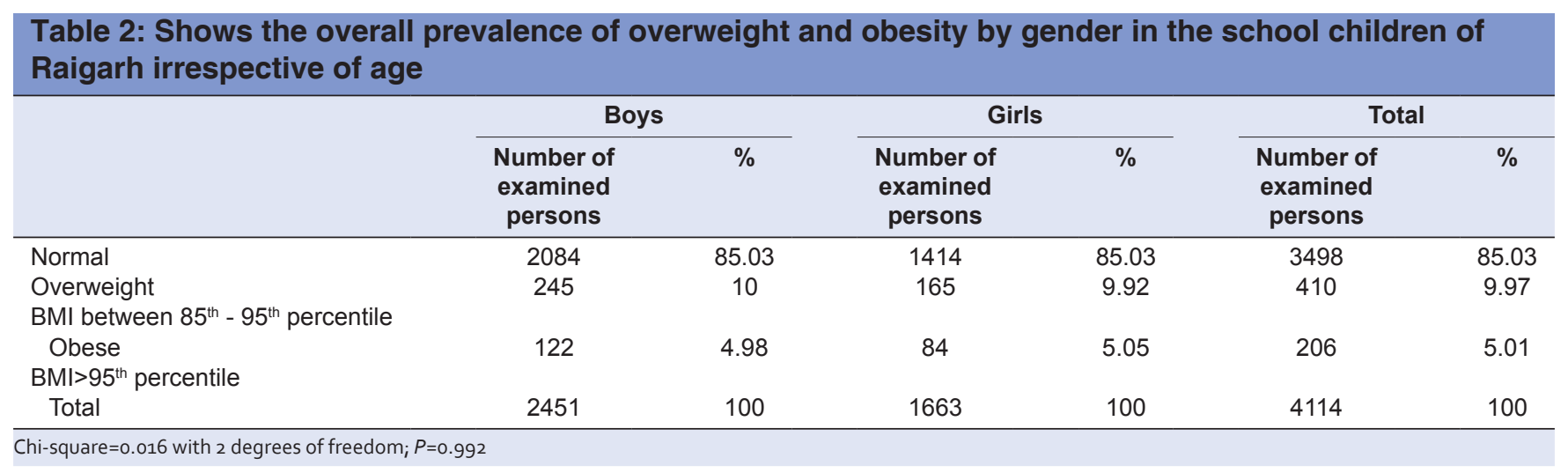

\begin{tabular}{|c|c|c|c|c|c|c|c|c|c|c|c|c|c|}
\hline \multirow{2}{*}{$\begin{array}{l}\text { Age and } \\
\text { sex }\end{array}$} & \multirow{2}{*}{$\begin{array}{c}\text { Number of } \\
\text { examined persons }\end{array}$} & \multirow[t]{2}{*}{ Mean } & \multirow{2}{*}{$\begin{array}{c}\text { Standard } \\
\text { error of mean }\end{array}$} & \multicolumn{10}{|c|}{ Body mass indices (percentile) } \\
\hline & & & & $3^{\text {rd }}$ & $5^{\text {th }}$ & $10^{\text {th }}$ & $25^{\text {th }}$ & $50^{\text {th }}$ & $75^{\text {th }}$ & $85^{\text {th }}$ & $90^{\text {th }}$ & $95^{\text {th }}$ & $97^{\text {th }}$ \\
\hline \multicolumn{14}{|l|}{ Male } \\
\hline 4 years & 152 & 14.53 & 0.16 & 11.44 & 12.01 & 12.46 & 13.11 & 14.41 & 15.57 & 16.54 & 17.56 & 18.75 & 19.37 \\
\hline 5 years & 157 & 14.73 & 0.17 & 12.4 & 12.53 & 12.75 & 13.46 & 14.36 & 15.45 & 16.29 & 16.61 & 18 & 19.58 \\
\hline 6 years & 193 & 15.13 & 0.17 & 12.13 & 12.3 & 12.63 & 13.63 & 14.61 & 16.07 & 17.13 & 18.23 & 19.07 & 20.81 \\
\hline 7 years & 188 & 15.58 & 0.18 & 12.34 & 12.69 & 13.14 & 13.89 & 15.1 & 16.36 & 17.68 & 18.82 & 20.99 & 22.77 \\
\hline 8 years & 158 & 16.13 & 0.23 & 12.71 & 13.01 & 13.3 & 14.25 & 15.39 & 17.35 & 18.75 & 19.99 & 22.35 & 23.46 \\
\hline 9 years & 188 & 16.33 & 0.22 & 12.62 & 12.86 & 13.33 & 14.18 & 15.59 & 17.58 & 19.38 & 20.34 & 22.39 & 23.64 \\
\hline 10 years & 184 & 17.38 & 0.24 & 13.1 & 13.3 & 13.7 & 14.9 & 16.66 & 19.56 & 20.88 & 22.31 & 23.36 & 25.28 \\
\hline 11 years & 211 & 17.34 & 0.24 & 12.87 & 13.22 & 13.99 & 14.91 & 16.64 & 18.48 & 20.52 & 22.96 & 24.98 & 26.57 \\
\hline 12 years & 199 & 18.42 & 0.25 & 13.73 & 14.05 & 14.53 & 15.77 & 17.53 & 20.79 & 22.34 & 23.26 & 25.64 & 26.29 \\
\hline 13 years & 191 & 19.47 & 0.28 & 14.25 & 14.44 & 15.33 & 16.67 & 18.91 & 21.43 & 23.23 & 24.93 & 27.34 & 28.55 \\
\hline 14 years & 177 & 19.49 & 0.27 & 14.66 & 14.87 & 15.47 & 16.82 & 18.55 & 21.67 & 23.34 & 24.43 & 26.34 & 28.41 \\
\hline 15 years & 143 & 20.29 & 0.34 & 14.97 & 15.38 & 15.95 & 17.18 & 19.43 & 22.84 & 25.09 & 26.59 & 28.58 & 29.41 \\
\hline 16 years & 185 & 20.71 & 0.29 & 15.53 & 15.93 & 16.46 & 17.65 & 19.54 & 22.85 & 24.9 & 26.25 & 28.33 & 30.27 \\
\hline 17 years & 94 & 22.01 & 0.44 & 15.93 & 16.32 & 16.98 & 18.45 & 21.51 & 24.59 & 26.3 & 27.67 & 31.03 & 32.71 \\
\hline 18 years & 30 & 21.29 & 0.7 & 15.35 & 15.48 & 17.24 & 17.7 & 20.07 & 24.91 & 25.89 & 27.24 & 28.1 & 28.12 \\
\hline 19 years & 1 & 19.06 & & 19.06 & 19.06 & 19.06 & 19.06 & 19.06 & 19.06 & 19.06 & 19.06 & 19.06 & 19.06 \\
\hline \multicolumn{14}{|l|}{ Female } \\
\hline 4 years & 105 & 14.22 & 0.16 & 12 & 12.01 & 12.19 & 13.09 & 13.98 & 15.14 & 16.02 & 16.57 & 17.03 & 18.37 \\
\hline 5 years & 127 & 14.57 & 0.16 & 12.01 & 12.51 & 12.78 & 13.38 & 14.24 & 15.11 & 15.89 & 16.85 & 18.71 & 19.48 \\
\hline 6 years & 131 & 14.98 & 0.21 & 11.61 & 12.02 & 12.67 & 13.47 & 14.42 & 16.23 & 17.16 & 18.06 & 19.75 & 20.49 \\
\hline 7 years & 123 & 15.06 & 0.19 & 12.16 & 12.33 & 12.95 & 13.66 & 14.72 & 16.16 & 17.18 & 17.8 & 18.62 & 20.63 \\
\hline 8 years & 126 & 16.05 & 0.25 & 11.84 & 12.55 & 12.97 & 14.2 & 15.19 & 17.8 & 19.39 & 20.21 & 21.76 & 22.58 \\
\hline 9 years & 134 & 15.98 & 0.23 & 12.63 & 12.7 & 13.02 & 14 & 15.42 & 17.69 & 18.33 & 20.01 & 20.61 & 22.09 \\
\hline 10 years & 112 & 17.4 & 0.32 & 12.93 & 13.2 & 13.55 & 14.75 & 16.93 & 19.44 & 21.35 & 22.42 & 23.81 & 24.01 \\
\hline 11 years & 107 & 18.04 & 0.29 & 13.54 & 13.7 & 14.63 & 15.79 & 17.36 & 19.92 & 21.08 & 22.07 & 23.59 & 25.04 \\
\hline 12 years & 122 & 18.79 & 0.32 & 13.35 & 14.05 & 14.96 & 16.02 & 18.07 & 20.44 & 22.37 & 24.38 & 26.52 & 28.04 \\
\hline 13 years & 102 & 19.54 & 0.37 & 14.37 & 14.78 & 15.57 & 17.02 & 18.75 & 21.66 & 22.96 & 23.54 & 24.94 & 27.88 \\
\hline 14 years & 131 & 20.18 & 0.27 & 15.29 & 15.47 & 16.05 & 17.94 & 19.74 & 22.66 & 23.56 & 24.03 & 26.08 & 27.43 \\
\hline 15 years & 114 & 20.42 & 0.35 & 15.18 & 15.6 & 16.03 & 17.74 & 19.8 & 22.84 & 24.61 & 25.67 & 26.94 & 27.7 \\
\hline 16 years & 126 & 21.1 & 0.28 & 15.61 & 15.92 & 16.87 & 18.77 & 20.72 & 23.31 & 25.19 & 25.7 & 26.62 & 26.95 \\
\hline 17 years & 87 & 22.03 & 0.42 & 15.69 & 16.71 & 17.34 & 19.05 & 21.55 & 24.72 & 26.59 & 27.49 & 29.03 & 30.22 \\
\hline 18 years & 14 & 20.99 & 1.36 & 15.35 & 15.35 & 16.12 & 18.25 & 20.56 & 22.04 & 23.38 & 30.21 & 36.78 & 36.78 \\
\hline 19 years & 2 & 19.42 & 1.28 & 18.14 & 18.14 & 18.14 & 18.14 & 19.42 & 20.69 & 20.69 & 20.69 & 20.69 & 20.69 \\
\hline
\end{tabular}

\section{DISCUSSION}

This report provides the most resent anthropometric reference data for children and adolescent of Chhattisgarh state. Over the last four decades the food environment has changed drastically. The environment has changed progressively to favour the consumption of calorically dense foods with the availability of fast food with lower prices per calorie for less healthy foods, and their increased advertisement. For children especially, budgetary constraints and increasing pressure to perform well in academics, poor neighbourhood with unsafe places for 
outdoor activities, the advent of television, computers and video games has resulted in opportunities for sedentary activities that do not been calories or exercise muscles ${ }^{3}$.

Complications of paediatric obesity occurs during childhood and adolescence and persists into adulthood, immediate co morbidities include type 2 diabetes, hypertension, hyperlipidemia and non alcoholic fatty acid liver disease. ${ }^{3}$ Studies from different parts of the world and from India itself are suggestive of such similar trends.

In the present study the overall prevalence of obesity and overweight was 5 percent and 9.97 percent respectively. Similar trend of obesity and overweight was found by Subramanium (2003) as 9.62 percent and 5.94 percent. ${ }^{17}$ Sharma et al (2007) reported the highest prevalence of overweight as 22 percent whereas that of obesity as 6 percent in Delhi. ${ }^{18}$

A multicentric study by Misra et al on around 30,000 students reported the prevalence to be of 14.4 percent and 2.8 percent in children for overweight and obesity respectively. ${ }^{10}$ Mahajan et al (2011) in Puducherry reported an overall rate of obesity of around 2.21 percent with the prevalence of overweight of 4.4 percent, which was seen as 4.24 percent and 4.58 percent respectively for over weight in boys and girls. ${ }^{11}$ Jain et al (2010) reported a high prevalence rate of 18.36 percent and 19.7 percent among boys and girls of Meerut for overweight and 10.82 percent and 5.3 percent respectively for obesity. ${ }^{14}$

In the present study the prevalence of obesity and overweight was less the 1 percent in age $<$ Gyears, in the age group between 7 to 9 years there is a gradual increase in the trend with the prevalence of obesity being less than 1.5 percent and overweight between $2.5-4.3$ percent. A Steep rise is seen in the trends of overweight and obesity from age groups $>10$ years with the highest prevalence seen in ages $14-18$ years.

These findings suggest that children belonging to pubertal and post pubertal age groups are at high risk of being overweight and obese. Strength of our study remains in the fact that it provides an overview of burden of childhood obesity among representative sample of children between 4-19 years for the $1^{\text {st }}$ time in state of Chhattisgarh and can prove to be a benchmark for future comparison by the public health personnel and policy makers of the state.

\section{CONCLUSION}

Indian expenditure on the health care system of its total GDP is far less as compared to some developed nations, thus an added on burden by the new found and rapidly increasing non communicable disease, obesity should by focused more upon during policy making at National level.

\begin{tabular}{|c|c|c|c|c|c|c|c|c|c|c|c|c|c|}
\hline \multirow[t]{2}{*}{ Age } & \multirow{2}{*}{$\begin{array}{c}\text { Number of } \\
\text { examined persons }\end{array}$} & \multirow[t]{2}{*}{ Mean } & \multirow{2}{*}{$\begin{array}{c}\text { Standard } \\
\text { error of mean }\end{array}$} & \multicolumn{10}{|c|}{ Body mass indices (percentile) } \\
\hline & & & & $3^{\text {rd }}$ & $5^{\text {th }}$ & $10^{\text {th }}$ & $25^{\text {th }}$ & $50^{\text {th }}$ & $75^{\text {th }}$ & $85^{\text {th }}$ & $90^{\text {th }}$ & $95^{\text {th }}$ & $97^{\text {th }}$ \\
\hline 4 years & 257 & 14.4 & 0.11 & 11.76 & 12.02 & 12.3 & 13.13 & 14.21 & 15.39 & 16.3 & 16.97 & 17.97 & 18.85 \\
\hline 5 years & 284 & 14.66 & 0.12 & 12.4 & 12.53 & 12.76 & 13.4 & 14.33 & 15.34 & 16.12 & 16.7 & 18.35 & 19.29 \\
\hline 6 years & 324 & 15.07 & 0.13 & 11.89 & 12.3 & 12.65 & 13.6 & 14.61 & 16.07 & 17.15 & 18.08 & 19.12 & 20.54 \\
\hline 7 years & 311 & 15.37 & 0.13 & 12.31 & 12.55 & 13.1 & 13.79 & 14.98 & 16.31 & 17.37 & 18.31 & 20.19 & 22.07 \\
\hline 8 years & 284 & 16.09 & 0.17 & 12.49 & 12.77 & 13.16 & 14.24 & 15.27 & 17.48 & 19.05 & 20.19 & 21.92 & 22.84 \\
\hline 9 years & 322 & 16.19 & 0.16 & 12.63 & 12.74 & 13.19 & 14.11 & 15.51 & 17.63 & 18.9 & 20.1 & 21.22 & 22.99 \\
\hline 10 years & 296 & 17.39 & 0.19 & 13.01 & 13.28 & 13.68 & 14.81 & 16.72 & 19.48 & 21.22 & 22.42 & 23.43 & 24.53 \\
\hline 11 years & 318 & 17.58 & 0.19 & 13.1 & 13.45 & 14.14 & 15.27 & 16.8 & 19.19 & 20.84 & 22.35 & 24.42 & 25.38 \\
\hline 12 years & 321 & 18.56 & 0.2 & 13.7 & 14.05 & 14.66 & 15.85 & 17.84 & 20.61 & 22.33 & 23.7 & 25.62 & 26.93 \\
\hline 13 years & 293 & 19.49 & 0.22 & 14.29 & 14.57 & 15.44 & 16.75 & 18.83 & 21.5 & 23.15 & 24.22 & 26.65 & 28.09 \\
\hline 14 years & 308 & 19.78 & 0.19 & 14.84 & 15.25 & 15.85 & 17.15 & 19.28 & 21.93 & 23.49 & 24.08 & 26.08 & 27.58 \\
\hline 15 years & 257 & 20.35 & 0.24 & 15.03 & 15.5 & 15.96 & 17.43 & 19.61 & 22.82 & 24.91 & 26.09 & 27.65 & 28.8 \\
\hline 16 years & 311 & 20.87 & 0.21 & 15.6 & 15.97 & 16.63 & 18.03 & 20.24 & 23.07 & 25.12 & 26.13 & 27.22 & 28.78 \\
\hline 17 years & 181 & 22.02 & 0.3 & 16.07 & 16.59 & 17.15 & 18.9 & 21.53 & 24.61 & 26.32 & 27.47 & 30.08 & 31.2 \\
\hline 18 years & 44 & 21.2 & 0.64 & 15.35 & 15.41 & 17.06 & 17.86 & 20.37 & 23.92 & 25.78 & 26.67 & 28.11 & 33.75 \\
\hline 19 years & 3 & 19.3 & 0.75 & 18.14 & 18.14 & 18.14 & 18.14 & 19.06 & 20.69 & 20.69 & 20.69 & 20.69 & 20.69 \\
\hline
\end{tabular}


There is an urgent need of increasing awareness regarding the same among the health care personnel and community at large. It also indicates the need to devise meaningful control measures both, at school and home and further research on risk factors for childhood obesity and to monitor trend in near future to the alarming rise in the number of paediatric diabetics and hypertensive patients.

\section{ACKNOWLEDGEMENTS}

The author is highly obliged for the help extended by the authorities of the school, especially Dr. R.K. Trivedi, principal, O.P. Jindal High School, Raigarh. The unconditional support by the authorities and the teachers of the school.

\section{REFERENCES}

1. Manju R and Krishna KR. Obesity in children and adolescents. Indian J Med Res 2010; 132: 598-607.

2. Shetty PS. Nutrition transition in India. Public Health Nutr 2002; 5: 175-182.

3. Gahagan S. Overweight and obesity. In:Kleigman, Stanton, St. Geme, Schor, Behrman, editors. Nelson textbook of Paediatrics, $19^{\text {th }}$ edition: WB Saunders: 2013. P .179-188.

4. World Health Organization. Preventing chronic diseases: A vital investment. World Global report. Geneva: World Health Organization; 2005.

5. Kosti RI and Panagiotakos DB. The epidemic of obesity in children and adolescents in the world. Cent Eurp J Public Health 2006; 14: 151-159.

6. Gedam SD. Childhood Obesity - challenges in the Indian scenario. IJMRR 2013; 1(1) 1: 1-4.
7. Wang L, Kong L, Wu F, Bai Y and Burton R. Preventing chronic disease in China. Lancet 2005; 366:1821-1824.

8. Strauss $\mathrm{J}$ and Pollack HA. Epidemic increase in childhood overweight, 1986-1998. JAMA 2001; 286:2845-2848.

9. Salmon J, Timperio A, Cleland V and Venn A. Trends in children physical activity and weight status in high and low socioeconomic status areas of Melbourn, Victoria, 1985-2001. Aust N Z J Public Health 2005; 29:337-342.

10. Misra A, Shah P, Goel K, Hazra DK, Gupta R, Seth P, et al. The high burden of obesity in urban Indian school children: a multicentric study of 38,296 children. Ann Nutr Metab 2011; 58 (3):203-211.

11. Mahajan P, Purty JA, Singh Z, Johnson C, Murugan N, Sandeep $A$ and Senthil V. Study of childhood obesity among school children aged $6-12$ years in Union Territory of Puducherry. Indian J Comm Medicine 2011; 26(1): 45-50.

12. Vohra R, Bharadwaj $P$, Srivastav JP, Srivastav $S$ and Vohra A. overweight and obesity among school going children of Lucknow city. J family comm Med 2011; 18(2): 59-62.

13. Chakraborty P, Dey S, Pal R, Kar S, Zaman FA and Pal S. Obesity in Kolkata Children: Magnitude in relation to hypertension. J Nat Sci Bio Med 2011; 2(1): 101-106.

14. Jain S, Pant B, Chopta $H$ and Tiwari R. Obesity among adolescents of affluent public schools in Meerut. Indian J Public Health 2010: 54(3): 158-160.

15. Premanath M, Basavanagowdappa H, Shekar MA, Vikram SB and Narayanappa D. Mysore childhood obesity study. Indian Peadt 2010; 47(2): 171-173.

16. Paediatric obesity. In. Kleinman RE editor, Paediatric Nutrition Handbook. $6^{\text {th }}$ edition. American Academy of Paediatrics. 2009, pp 733-759.

17. Subramanyam V, Jayshree $R$ and Rafi $M$. Prevalence of overweight and obesity in affluent girls in Chennai in 1981 and 1998. Indian Paedtr 2003; 40:332-336.

18. Sharma A, Sharma K and Mathur KP. Growth pattern and prevalence of obesity in affluent school children of Delhi. Public Health Nutr 2007; 10 (5):485-491. 